\title{
Assessment on Development Level of Sport Industry Based on Data Mining
}

\author{
Song Yupeng ${ }^{1}$, Jia Ling ${ }^{1}$ \\ 1.Zhuhai College of Jilin University, Guangdong Zhuhai, 519000, China
}

Key words: sport industry; development; necessity; status analysis

\begin{abstract}
Sport industry is the inevitable outcome of market economy, while sport socialization and industrialization is the inevitable course for sport development. The Thesis proposes matters needing attention in sport industry development direction and development courses in our country, integration of sport industry and transitional industries, development of public benefit sport causes of sports lottery and support for advantageous enterprises to enter the market for financing, by beginning from necessity of developing sport industry in our country, comparing sport industry in our country and international sport industry pointedly, which is a directional scientific achievements with certain reference functions to sport industrialization development.
\end{abstract}

\section{Necessity to develop sport industry in our country}

With continuous deepening of construction of market economy system in our country and continuous development of sport carriers, sports' relatively single socialized function in planned economy era on inspiring national spirit, motivating national confidence and developing physical power of people is moving toward diversified development function, and economical function as a kind of industry in marketization is gradually expressed, therefore sport industry has become a new excitement for national economy growth. Sport industry is a social organization system connected with commodity and marketed, characterized with socialized mass production and modern operation and regarding production and consumption of sports goods as its core. Original State Physical Culture and Sport Commission divides sports into three types-pure sport industry, sport-related industry and PE owned industry in Outline of Sport Industry Development. Though this division is not precise enough, it basically covers social production and organization elements of sport industry. Under current social and economic environment in our country, sport industry should include: sport fitness entertainment industry, sport goods manufacturing industry, sport service industry, sport labor service industry, sport information consulting industry, sport tourist industry, sport construction industry and sport finance and insurance industry, etc.

\section{Development situation of sport industry}

In August 2002, Hong Kong Sports Development Board issued a report named The Economic Impact of Sport which carried out special investigation and research on development situation of Hong Kong sport industry and basic situation of sport population in Hong Kong. In 2000, total output value of Hong Kong sport industry was 38.268 billion Hong Kong Dollars, achieving added value of 20.1 billion Hong Kong Dollars and accounting for 1.5\% of Hong Kong GDP; Employed population of sport industry was 61339 people, accounting for $2 \%$ of employed population in Hong Kong. Hong Kong Sports Development Board also carried out special research on driving role of sport industry on Hong Kong national economy, which indicated that estimated value of total economical influence brought by Hong Kong sport industry to Hong Kong economy was 26 billion Hong Kong Dollars each year, accounting for $2.1 \%$ of Hong Kong GDP (refer to Table 1). 
Table 1 Development of Hong Kong Sport Industry in 2000

\begin{tabular}{cccc}
\hline Industry category & $\begin{array}{c}\text { Quantity of employed } \\
\text { population }\end{array}$ & $\begin{array}{c}\text { Value added (million Hong } \\
\text { Kong Dollars) }\end{array}$ & $\begin{array}{c}\text { Gross output (million Hong } \\
\text { Kong Dollars) }\end{array}$ \\
\hline Sportswear and sneaker manufacture & 9419 & 1946 & 6729 \\
Manufacture of sport equipment & 541 & 153 & 593 \\
Wholesale of sports goods & 474 & 79 & 151 \\
Retailing of sports goods & 1577 & 231 & 606 \\
Import and export trade of sports goods & 17226 & 6833 & 12403 \\
Service of fitness centers & 9428 & 3189 & 5224 \\
Service of stadiums & 11725 & 3965 & 6496 \\
Service of Sports Development Board & 788 & 266 & 436 \\
and sport education & 10162 & 3437 & 5630 \\
Competitions & 61339 & 20100 & 38268 \\
Total & 1.91 & 1.58 & 1.65 \\
\hline
\end{tabular}

According to estimated results of Sport Business Journal-American famous sport industry magazine in 2002, added value of American sport industry in 2001 had reached 194.64 billion dollars, accounting for 2\% of American GDP. With employed population of 2.949 million people, sport industry had become the seventh industry in America. During 1980s to 1997, development speed of American sport industry was quick and added value of sport industry increased from 47 billion dollars in 1986 to 168 billion dollars. After 1997, American sport industry enters a slow-growth phase (refer to Fig. 1).

Fig. 1 Growth of Added Value of American Sport Industry in 1986-2001 (unit: 1 billion dollars;

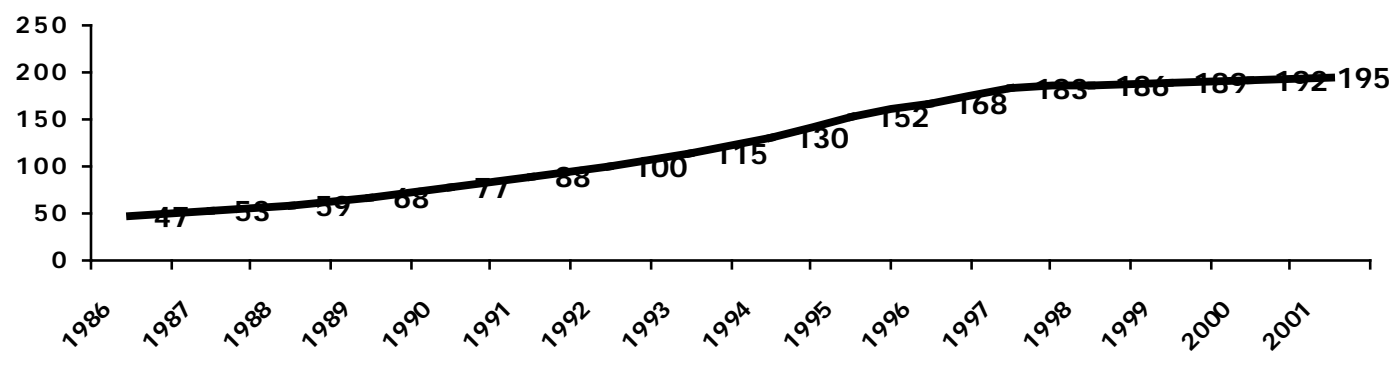

source: Sport Business Journal)

According to statistics results of Australian Bureau of Statistics, in 2000-2001, total output value of Australian sport industry was 8.6 billion Australian Dollars (about 5.308 billion dollars, excluding sports good manufacturing industry and sports good sales industry), of which, sport filed and facilities industry was the industry with the highest income: its total output value reached 3.563 billion Australian Dollars; total output value of competition and performance industry reached 1.382 billion Australian Dollars; sport administrative organization industry reached 1.147 billion Australian Dollars; horse racing and dog racing industry was 1.136 billion Australian industry. In 2000-2001, added value achieved by Australian sport industry was 1.942 billion Australian Dollars (1.199 billion dollars). As of June 2001, employed population of Australian sport industry was 87447 people, of which 30547 people were regular workers, while volunteers of sport industry reached 178837 people.

In 2000, added value of British sport industry was 15.2 billion pounds, taking up 1.8\% of Britain GDP. In 2000, employed population of British sport industry was 450 thousand people, making up $1.6 \%$ of British employed population. In 1990, added value of British sport industry was 8.9 billion pound, therefore added value of British sport industry in 1990s increased by 70\% which exceeded growth speed of nationwide GDP.

According to estimation of Statistics Canada, in 2000, added value of Canadian sport industry was 8.9 billion dollars, accounting for $1.1 \%$ of Canada GDP; employed population of sport industry was 262325, taking up $2 \%$ of nationwide employed population in Canada. 


\section{Countermeasures}

Devoting major efforts into modern service industries are basic strategy for national economy restructure and industrial restructuring in our country, and also an important action to promote sustainable development of national economy and implement scientific development concept and a top priority among development strategies of sport industry in country. Only devoting major efforts into the sport service industry is able to optimize sport industry structure in our country, reverse long-term left-behind situation of the sport service industry, give full play to main channel function of the sport service industry in taking in employed population and promoting economical growth and achieve sustainable development of sport industry in our country.

First, actively encourage non-state economies to invest in sport service industry by preparing practicable specialized industry structure policies. Government departments should prepare specialized policies for industry structure by scientific methods, actively encourage private enterprises, individuals, investor from Hong Kong, Macao, Taiwan and foreign countries to engage in developing sport competitions, national fitness, sport agency, sport training, sport consulting, stadium service and other sport operation activities and establish operation entities by capital, technology, information, operation management and other forms. Government departments should provide convenience regarding market access, industrial and commercial registration, land use, credit tax, depreciation of fixed assets, labor employment and other aspects. Ownership structure and capital structure of sport service industry in our country can be further optimized by above methods.

Second, Push development of sport service industry by using fiscal levy and other series policy levers. For a long time, relevant government departments in our country regard the fitness service industry as other entertainment industry, collect high taxes and collect the same expenses for water, power, coal and other fuels as industry, which seriously limits development of fitness service industry in our country. To cultivate sport service industry in our country, in aspect of tax policies, the nation should promote rapid development of sport service industry, expand total quantity of sport service industry and optimize sport industry structure by preparing preferential policies (such as, tax relief, differential tax rate, land use rate, etc.) and other preferential policies on use of water, electricity, coal and other energy.

Third, promote development of sport service industry though investment and financing policies. It is suggested that part of public welfare fund of Chinese sports lottery should be used to support investment programs of nationwide fitness service industry with development potential, the government should support sport service industries with advantages entering the capital market for providing fund guarantee for development of sport service industry through stock exchange listing, enterprise bonds issuing, program financing, share right replacement and other methods.

\section{Reference}

[1] Liu J, Feng X W, Li J, et al. Cyber Security Situation Awareness Based on Data Mining[J]. Advanced Materials Research, 2014, 756-759(756-759):4336-4342.

[2] Chen J, Hu B, Moore P, et al. Electroencephalogram-based emotion assessment system using ontology and data mining techniques[J]. Applied Soft Computing, 2015, 30:663-674.

[3] Liu F R, Chen J S. Prediction and assessment of student learning outcomes in calculus a decision support of integrating data mining and Bayesian belief networks[C]// Computer Research and Development (ICCRD), 2011 3rd International Conference on. 2011:299 - 303.

[4] Rezania M, Javadi A A, Giustolisi O. An evolutionary - based data mining technique for assessment of civil engineering systems[J]. Engineering Computations, 2008, 25(6):500-517.

[5] Liu J, Feng X W, Li J, et al. Cyber Security Situation Awareness Based on Data Mining[J]. Advanced Materials Research, 2014, 756-759(756-759):4336-4342. 